\title{
Critical Thinking in the EFL Workshop on War: A Case Study
}

\author{
Maja Mandić \\ University of Banja Luka, Bosnia and Herzegovina \\ maja.mandic@ flf.unibl.org
}

DOI: http://doi.org/ 10.36892/ijlls.v2i4.388

$\begin{array}{ll}\begin{array}{l}\text { Received: } \\ \text { 01/09/2020 }\end{array} & \text { Abstract } \\ \text { Accepted: } & \text { This article presents a small case-study of an EFL workshop class on war, } \\ \text { 10/12/2020 } & \text { teaching. The development of critical thinking skills is one of the priorities of } \\ & \text { higher education, especially when discussing a sensitive issue, so the } \\ & \text { workshop was organized around the topics of war and memory. The students } \\ \text { Keywords: } & \text { were given individual research assignments to prepare in advance, which they } \\ \text { critical thinking; } & \text { presented in the workshop. The teacher was only a moderator as the students } \\ \text { content-based } & \text { were responsible for their presentations and discussion. The outcomes of this } \\ \text { teaching; EFL } & \text { process are presented in the article, focusing on the students' delivery of their } \\ \text { teaching; war; } & \text { assignments. Based on the teacher's observations and students' responses to } \\ \text { workshop } & \text { the workshop, it can be concluded that it was possible to combine some of the } \\ & \text { fundamentals of critical thinking with those of content-based teaching for this } \\ & \text { class. The article discusses how the students benefited from the class in terms } \\ \text { of acquired knowledge, linguistic skills and motivation. It also outlines the } & \text { challenges of organizing the workshop and dealing with the sensitive topic of } \\ \text { war. The article proposes practices which could be used to improve the } & \text { observed positive aspects and to remedy the negative ones. }\end{array}$

\section{INTRODUCTION}

Foreign language teachers have adopted many different approaches to teaching grammar-translation approach, audio-lingual approach, the structural approach, Total Physical Response, communicative language teaching, immersion, to name just a few - and have worked within different theoretical frameworks, such as structural, cognitive, functional, to mention just some of the most commonly used theories. As already noted by theorists, there has been a greater need for holistic approaches in teaching (as opposed to the basic skills approach), with a larger focus on knowledge combined with self and the world, as well as others' perspectives on these (Shuy, 1981; Allison, 2014; Yassin, Razak, \& Maasum, 2019). The focus on knowledge of the world and self implies the development of thinking skills which must be at the center of learning, and the ideal framework for such manner of teaching is the critical thinking approach. Critical thinking helps students realize the broader picture in discussing various topics in class, especially if those are sensitive topics, by simultaneously developing critical thinking skills and linguistic skills (Brookfield, 2012; Buskist and Irons, 2008; Moore, 2013; Ennis, 2002, 2011; Facione, 2007; Paul and Elder, 2005; Pineda, 2004).

Setting up a university-level foreign language class as a workshop was an attempt to organize a class beyond the limits of a traditional learning situation and engage students in a 
discussion as one of the most important activities within critical thinking teaching (Rezaei, Derakhshan and Bagherkazemi, 2011). It was also an attempt to work on students' linguistic and common knowledge pertaining to various fields of humanities (history, literature, psychology) by making students do their own research within the framework of contentbased learning prior to the workshop class (Dupuy, 2000; Liaw, 2007; Met, 1991; Stoller, 1997). The article discusses the teacher's observations of the class and students' performance and feedback, focusing on the positive and negative results of those observations. The students' feedback was overall positive and their performance can be improved in future classes of the same format but with the proposed corrections made.

The article is organized in five sections, with the first one introducing the idea and the theoretical framework used in class. Section 2 outlines the literature written about the critical thinking learning and teaching and content-based language teaching. Section 3 is the longest chapter of the paper and it describes the idea behind the case study, the teacher's plan of work, the organization of the class, and the student group involved. It also discusses the aims of the workshop, the topics discussed by the students, the classroom layout, the students' delivery of their presentations and their group discussion. Section 4 focuses on the observed positive and negative aspects of the workshop class on war, giving possible reasons for the negative ones. It also presents the conclusions drawn by the students during and after the discussion. The final section, Section 5 sums up the advantages and disadvantages of organizing the workshop class on war and proposes further approaches to organizing this type of class and research questions.

\section{LITERATURE REVIEW}

When foreign language teachers decide on how to organize a class and present the material contained in the syllabus, they are faced with different approaches to teaching and it is sometimes difficult to select a proper one. There is no doubt, however, that teachers always have their students' benefits and satisfaction in mind and try to maximize their students' potential by giving them the opportunity to develop their linguistic skills as well as their cognitive competencies (Brown, 2004). An approach that can make students achieve the best results and prepare them for their future education and life is critical thinking.

The term seems to evade clear definition although most educators intuitively know at least what the basic concept of critical thinking is (Atkinson, 1997). As Moore pointed out, the concept of critical thinking can only be understood as "an educational practice", rather than an abstract idea with a vague, varying meaning. Moore agrees with Williams' idea of "extra edge of consciousness" (1976) as the best description of what critical thinking entails (as cited in Moore, 2013). In more specific terms, what this teaching approach aimed to achieve was the development of several key elements encompassed by how the concept of critical thinking is used in university education: critical thinking as a skeptical and provisional view of knowledge, critical thinking as a careful and sensitive reading of text, and critical thinking as the adopting of an ethical and activist stance (Moore, 2013). The main aim of teaching in general is to develop skills in students that would help them attain different forms of knowledge throughout and after their formal education, among which analysis, inference and explanation are the most important ones because they all lead to self-regulation, which makes students always question and correct their own reasoning or results (Facione, 2007). All these aspects of critical thinking are the reasons which motivated the idea of organizing the workshop class on war. This, however, cannot be achieved over the course of one semester or even a whole academic year, as it is an ongoing process that is mastered our whole life and is based on continuous practice and reflection on the part of both students and their teachers (Pineda, 2004). Despite the short time for the workshop class and all the other 
assignments over the semester, some results could be observed and they are discussed in Section 4.

Responding reasonably to new information is at the core of critical thinking (Gomez and Leal 2015), which means that developing any skills that might lead to such manner of treating new as well as old content is essential in higher education. As pointed out by Paul and Elder (2005), critical thinking must play a crucial role in education if the society wants students to develop mental skills essential for functioning well in this complex world. Extremely important observations come from Ennis, who designed the FRISCO approach (focus, reasons, inference, situation, clarity and overview) with a special emphasis on understanding and evaluating an argument, and also produced a list of attributes of a critical thinker. Among these attributes are open-mindedness, good judgment of credibility of sources, formulation of plausible hypotheses, and good judgment of the quality of an argument. (Ennis, 2002, 2011)

An effective technique to developing students' critical thinking skills is content-based language teaching, which is used to bring various interesting topics into the language classroom. Stoller (1997) argues that the pervasiveness of language in teaching different subjects and the close connection of oral and written language to thinking make contentbased language learning the best way of teaching higher-level thinking skills. With contentbased instruction, the focus is on content, which is crucial for developing language proficiency and responding to students' personal and professional needs. This type of instruction is also a welcome alternative to traditional foreign language teaching (Dupuy, 2000). Writing about content-based instruction, Met (1991) argues that content-based instruction has to be demanding for students and has to engage students cognitively so that they can develop the required skills and abilities. The focus on content during the preparation of the students' presentations, their engagement with textual or visual material on the topics, and their cognitive involvement in the presentations and discussion were all reasons why the content-based learning was a suitable choice for the workshop class.

\section{MATERIALS AND METHODS}

\section{Change of routine}

It may be difficult to create tasks and assignments which do not follow the pattern of grammar or vocabulary exercises most teachers and students are used to. Trying to find the best teaching practices which result in all the planned outcomes every class, teachers are likely to fail. This fact, however, should not prevent them from thinking of new forms of teaching which they can shape to fit the needs of each new groups of students they teach. There are several reasons why teachers might avoid introducing some elements of critical thinking in their teaching because it is complex and demanding both for teachers and students: some students are accustomed to learning information by heart because in critical thinking there is no certainty that facts provide; some students are used to being told what to do and how to do it, which relieves them of responsibility; some students think their knowledge is inferior to that of their teachers, who they see as an authoritative figure (and students were told to obey the authority); and finally, some students do not have the required knowledge to understand topics discussed, which makes it impossible for them to analyze and apply those topics. (Buskist and Irons, 2008)

Despite all these challenges, I decided to organize the semester around the assignments which are described in the following section. One third of the classes for the whole semester (10 out of 30) were replaced by individual take-home and in-class asignments which were to engage students more and keep them active and involved throughout the whole semester. This decision was based on the fact that students learn to think critically when they 
have the opportunities and reason to think in critical ways, when they see others engage in critical thinking, and when they are admitted into arguments, challenges, and debates based on respect rather than power or exploitation. (Smith, 1990, p.107)

\section{Semester outline}

In these five weeks, that were deliberately scheduled throughout the semester, the students were asked to translate a short text from English, write an argumentative essay, and write an image-based essay (all in-class assignments), and give a short presentation titled $A$ day in the life of $X Y$, and take part in the workshop (which both required some research prior to the class). Each in-class assignment was preceded by a preparation class the week before, and for each take-home assignments the instructions were given at least two weeks in advance. The intention was to transfer the learning process on the individual students and also to put them in charge of the teaching process too, at least for the duration of their short presentations and discussions afterwards. I also decided that all these tasks would replace the predictable "oral part" of the final examination because their translating, reading and speaking skills would already have been tested through the tasks of translation, writing an argumentative and image-based essays, and giving a presentation. As pointed out by theorists, assessment practices can be used to enhance crtical thinking among language learners, such as ongoing assessment and providing feedback (Shirkhani and Fahim, 2011), which were used in this case. The final grade consisted of the points the students earned for the described assignments (a maximum of 10 points was awarded for each assignment) and the points they earned on their test (based on the grammar and vocabulary in their textbook).

\section{Description of the student group}

All these tasks were possible to carry out because I worked with a relatively small group of students (15), which is the best possible environment for developing students' critical thinking skills (Brookfield, 2012). It would be quite a challenge to prepare and organize the presentations and, particularly, the workshop with a larger group of students. I believe their individual work and voices would not be heard properly if the group was bigger, especially with the number of classes we had that semester ( 2 classes a week - 90 minutes). The students were all German majors who decided to choose English as a foreign language as their elective course (among four foreign languages). Their command of English, for most of them, was at least at B2 level (and for some even higher), so I knew I could assign the described research projects and I was certain that they would be able to complete and benefit from them. I knew all of them very well - this was my fourth consecutive semester working with this group, so I knew exactly how much they could do and what I could ask them to complete. The students' response to the assignments described in the previous paragraph was very positive, judging by their very active engagement in classes, such as asking more questions, participating more in discussions, giving elaborate answers, showing interest in related topics, creating better atmosphere in class, among others. In addition to this, their final grades were better than in the previous semesters.

\section{War and workshop in focus}

This chapter discusses the organization, delivery and results of the workshop in detail, and focuses on what I observed in class and what I wrote down during the students' brief reports and comments afterwards. Given the fact that debates, forums and discussions can motivate students and increase their enthusiasm to critically think about topics from different perspectives, especially controversial ones (such as war) (Rezaei, Derakhshan and Bagherkazemi, 2011), there was no reason to believe that students would not benefit from the workshop class. 
The workshop class took place in March 2018 (the fifth week of the semester) and was organized with the following four aims in mind:

- to organize class in the form of a workshop (which is different from what students typically do)

- to talk about war 100 years after the end of the Great War (and to reflect on students' own experiences and memories)

- to practice speaking

- to reach conclusions

The students were informed about the aims of the workshop class at the beginning of the class, i.e. in the introductory part of the class. Making this introduction was almost all the work that I did in class in general. For the rest of the class I only spoke when I announced the first student to present his research and when I invited the students to give comments after all of them finished their presentations. The students spoke in the order in which they were sitting in the circle and did not need my assistance to start their presentations. The teacher's role in this class is that of a moderator, which transfers focus from the teacher to the student.

\section{Topics related to war}

Trying to give my students the freedom that they so often crave but also not wishing to burden them with too much work, and also aiming to tackle particular topics in class, I chose events and subjects that I thought were the most relevant and interesting as well as relatively unknown to my students. I did not assign the topics directly as students were allowed to pick the topics written on pieces of paper out of a paper bag. This eliminates any possible bias and makes the whole process more entertaining, for both the students and the teacher. This was carried out two weeks prior to the workshop, which allowed enough time for students to research their topics and prepare their five-minute presentations. The topics ranged from actual events to art to grand concepts covering many abstract as well as concrete ideas, and were all created based on one of the points for developing students' critical thinking which mentions a more holistic and cross-disciplinary analysis (Brookfield, 2012):

\section{The Christmas Truce}

Trauma

Guernica

$\operatorname{PTSD}(2)^{1}$

Memory (2)

Čovek peva posle rata $^{2}$

Napalm Vietnam Photo

Refugees (2)

Victim

Holocaust

These words were written on pieces of paper and were all designed to provide as much freedom to the students as they needed to adapt the chosen topic to their personal interests and preferences. Two of the topics (Guernica and Napalm Vietnam Photo) were copies of the original painting and photograph so the students who picked them were supposed to identify the image first and then present it to the other students in the workshop class. When writing their essays, students are usually given written topics to choose from, so

\footnotetext{
${ }^{1}$ (2) indicates that two students shared the same topic and had to decide between themselves what each of them would cover

${ }^{2}$ A Man Sings after the War, a poem by Dušan Vasiljev
} 
writing a short composition based on a photograph might be a positive change for them. Using visual material in class can be extremely useful and poses a challenge for students, which can provide additional motivation to complete their assignment (Donaghy and Xerri, 2017).

\section{Classroom layout}

For the purpose of the workshop, the classroom layout was changed from the traditional arrangement - instead, we arranged the tables in a circle so that no one had a more prominent position than anyone else. Rearranging the tables took 5 minutes of the class, which I thought was not a great loss because the benefits of such seating arrangement outweigh the loss of time.

After introducing the class and its main aims, I asked the students to each take their time and speak about their topic for up to 5 minutes. I invited the first student to talk, after which the other students just waited for their turn to speak, following the order in which they were sitting in a circle.

Everyone showed up in class (which rarely happened) but not everyone had prepared their presentation because they had not been aware of it. Two students who repeated the year and one student from the current group missed the class when I gave the instructions and were never informed by their classmates about the workshop. The students who did not have presenatations at the workshop were later given their own topics and presented them to me at the end of the semester, which, of course, was not the purpose of the class but I could think of no better way of organizing it.

\section{Students' presentations}

Before describing the process of the students' contribution to the workshop and their comments and responses to the teacher's questions, it is important to point out why a workshop class makes such a useful forum to discuss sensitive topics. Any class that encourages students to take active part in a discussion, to ask and answer questions and to reflect on different aspects of a broad topic is a successful class. Active learning methods are the best idea for a productive class. When students reflect deeply on a question, engage in discussions with other students and are expected to exlain their answers to their classmates, they use skills at the more advanced levels of Bloom's Taxonomy (1956). (Yuretich, 2004, p.44)

After the brief introduction described in Section 3, the students started delivering their presentations. The first student to present his work was one of the most eager students in that group, who always responded to the teacher's questions first in every class, so he volunteered to begin with the presentations.

Before he started speaking, Student $\mathrm{A}^{3}$ asked: "Should I stand up? ", to which all the other students shouted: "No!". His question could be interpreted in terms of how students are normally expected to behave in class, but his classmates' response could be seen as their wish to change that. The student talked about The Christmas Truce, mentioning basic information about this event: trench war, no man's land, the time and setting.

The next topic was trauma and Student B approached it as a medical term, as a psychological injury and how it is caused. This was one of the presentations that was very short, lasting only about 2 minutes.

Student $C$ spoke about refugees - the definition of the term, how many there are in the world and some of the organizations that deal with this population. His presentation was one of the shortest of all.

${ }^{3}$ I decided to change the students' real names in order to protect their identity. 
Student D spoke about memory and this was the first time somebody mentioned their personal experience. Student D talked about her father and his memory of war, or, to be more precise, his lack of willingness to talk about it. In her own words: "'He doesn't talk about it but it doesn't mean he's not aware of it." She emphasized that different people react differently to what happened to them, saying: "Some talk about it, others don't".

Next, Student E talked about a poem that I thought not many people knew but it turned out that she had read this poem in highschool, so only some learned about it in this class. I had asked Student E to read the poem in class (even though it was not originally written in English) because, in my opinion, this is one of the most poignant antiwar poems ever written and I wanted everyone to hear it at least once in their life. After reading it, she said the poem talked about the man's greatest wish, which was the wish for peace, and pointed out that everyone should read the poem and think about it. She also emphasized the position of the poet, who is portrayed as part of an unconscious crowd.

Student $\mathrm{F}$ was the second student to cover the topic of refugees and she decided to mention migrants as well, emphasizing migrants from Syria and Afghanistan in $\mathrm{BiH}$ and the problem of limited capacity of many countries to accept them.

Student $G$ had one of the best researched presentations. Her topic was to show and describe the world-famous photograph of a little naked girl in Vietnam after a napalm attack ${ }^{4}$. She talked about how the photograph changed the author's and the girl's lives, described how the photo was taken, how the author took the girl to the hospital, how the photo got published and showed more photographs by the same author. This presentation was more extensive than any other and the student was genuinely enthusiastic about it.

Student $\mathrm{H}$ talked about memory, just like Student D, but had a different, impersonal angle. She decided to focus on the rescue operation of an Englishman who saved around 700 Jewish children from the Czech Republic, who later thanked him in a documentary shown on BBC.

Student I and Student $\mathrm{J}$ decided to work in pair and take turns when presenting their research on Post-Traumatic Stress Disorder (PTSD). Student I mentioned differences between adults and children (children over 10 and adults are more affected), also between therapy and medication. He also spoke about shell shock and the first use of this term in the 1970s after the Vietnam War. Student J said what the definition was and spoke about different causes and situations when PTSD can occur (for example, as a reaction to huge stress).

One of the topics was also victims. Its definition was presented by Student K, pointing out: "I'm going to focus on war because if there's a war, there are bound to be victims". She decided to talk about children who were used for experiments and people whe are targeted for their race, religion and ideology. She added that we experienced civil war not so long ago but there are no winners.

Student L talked about Holocaust, a topic which I thought was unseparable from the topic of war. She said: "We all know the horrors of Holocaust and how it ended". She identified the political situation in Germany at the time as reasons for it but the whole presentation lasted less than 1 minute and I felt she did not give it due attention.

Student M presented Guernica, the famous Picasso's painting. She explained that it was painted as a comment on the Spanish civil war and that it became an antiwar symbol. Student M described the size, colors and technique of the painting, as well as the historical event behind it. She also mentioned how Picasso was inspired to paint it.

\footnotetext{
${ }^{4}$ The Napalm Girl by Nick Ut 


\section{Students' discussion}

The students' short presentations were followed by a discussion, where everyone was free to say whatever they wanted. A siginificant part of developing crtical thinking skills is asking and answering questions and, most importantly, to examine and reflect on them because "to learn well is to question well". (Elder and Paul, 2003, p.36) Building upon Elder and Paul's questions of information and questions of interpretation (2003, p.36), I introduced the discussion asking the following questions:

What topics were you aware of before the class?

What is the most important thing you heard in class?

What did this class make you think about?

The students best responded to the last question, which was in line with the aims of the workshop class. Questions of interpretation force students to examine how they organize and give meaning to information, which could lead them to ask more questions (such as questions of point of view, which make students examine their perspective and consider other relevant viewpoints), resulting in the better development of their critical thinking skills. (Elder and Paul, 2003, p.36)

The following report of their discussion at the end of the class is reconstructed based on the notes I took while the students were talking. I did not take part in their discussion as I wanted the students to have a conversation about the topics mentioned in class as well as anything else they could think of in the most spontaneous, natural way possible. As Paul and Elder emphasize, some of the essential parts of critical thinking is to raise vital questions and problems and think open-mindedly within alternative systems of thought (Paul \& Elder, 2005, p.5).

This is a short report of what the students thought was important to say:

Student N said: "War never changes". He added that throughout history we had never read about a war that the bad guys won. He did not think there was a big difference. Student $\mathrm{N}$ pointed out he was not defending anyone and the Nazis were demonized, but added there were Japanese concentration camps in the US. He also mentioned that in the USSR the communist ideology killed a lot more people than the Nazis (while talking about this, he said: "I don't know if you know this."). In his opinion, history is written about the victors.

Student $\mathrm{O}$ said he knew most of the things mentioned at the workshop. He added: "War demonstrates how quickly we can become monsters". He also added that the true nature of war was shown by the Christmas Truce, and how the governments manipulated everything. Student O mentioned schoolchildren on the battlefield.

Student P pointed out she had heard some new things. She also emphasized: "I do not want to hear about them as that is all a very bad thing".

Student K stated: "I do not know if it is a good or bad thing to remember war". She explained they were constantly reminded about bad sides. She added: "We were not involved in the war here but we are still regarded as enemies". She asked whether we should try to forget about it. She mentioned Kozara mountain.

Student $\mathrm{N}$ thought it was good to visit war museums. He remembered the first time he went to Kozara on a school trip and talked about how the children climbed the tanks and that it reminded them of video games. He explained how the teachers took them inside the museum and remembered a picture of a man with his head blown off, and how it was real. Student N said: "I was terrified". He added the same happened in Gradina ${ }^{5}$ with everything they saw. He said his own family suffered a lot in Prijedor. Student N concluded: "People should visit war museums because we should know what happened".

${ }^{5}$ Gradina is part of the WWII Extermination Camp Jasenovac 
Student O said: "Humans are the only species that kills for no reason". He compared people with cats who only kill for food. Sudent O pointed out: "War is a big machine for making money". He thought children should not be allowed to go to war museums because they could not understand the horror of it. He stated: "In today's society killing is normal". In his opinion, history books are not the whole story. He mentioned the psychological sides of warfare and the importance of propaganda. He pointed out: "What is good and what is bad are not fixed things".

Student $\mathrm{H}$ said she appreciated the artistic representation of war.

\section{RESULTS AND DISCUSSION}

\section{Positive and negative aspects}

As with any other project in the classroom, this one proved to have both good and bad sides. Teaching does not mean creating a universal teaching plan that would fit each and every student. Such a teaching plan does not exist because the needs of all the students in a group we are teaching at a time are different, as well as their interests, previous knowledge and personalities. There is no magic formula that could be applied to each new group of students at any level of English. Many students might be reluctant to accept the critical thinking approach because they are accustomed to being told what to do by teachers, they do not like to be responsible for their own learning process, they do not wish to express their opinions in front a teacher, who they consider superior to them, or they think that learning information by heart constitues successful learning. (Buskist and Irons, 2008) But the attempt to think of new approaches and projects, put them into practice and adapt them to new groups of students after they have been tested with previous groups is what constitutes good teaching.

In my observation, which is how I drew all the conclusions presented here, the workshop was a much better environment to discuss important and/or sensitive topics than any traditionally organized class. The circular seating arrangement breaks the atmosphere of a hierarchically designed class. The teacher becomes less visible and more as one of the group. The atmosphere becomes more comfortable and relaxing than that in a classroom with a traditional layout.

When the workshop finished, I asked the students if each of them learned at least one thing they had not heard before and they unanimously said they had. This indicates that one of the most important outcomes of any learning situation was achieved, i.e. new knowledge was acquired, because the students had more knowledge of the topic than before the class. It is often difficult to assess whether teaching a class based on critical thinking is effective and whether the outcomes of teaching critical thinking skills have been achieved. Teachers often use grades as indicators that students have learnt their subject matter but it is not easy to assess critical thinking skills as it is easy to assess the typical course content. (Buskist and Irons, 2008) It has to be noted that, in terms of the students' grades, this class was very effective as they all improved this semester. There are many other beneficial aspects of a class designed as a workshop, the most important of which are the following:

\section{1) Students do individual research before their classes}

Doing individual research provides students with an opportunity to engage in independent learning and to choose their own focus, methods and ways of delivery. They mostly rely on the use of internet, which is rich with various resources and helps students to come up with many different subtopics. This, however, can mislead students and confuse them to the point of losing focus, which might be a good time for their teacher's intervention. 
When asked to identify a photograph or painting, students do even more individual research and try to satisfy their own curiosity. They independently learn how to work with visual aids.

Drafting a short report teaches students to collect a great deal of information and choose what they think is the most relevant to the assignment. This can be a challenging task for them at this point of their studies but can be understood as a useful exercise for some future, more ambitious assignments. Another possible difficulty is the question of how broad or narrow the topic of their research is. The students were given just the basic instructions on how to conduct their research but they had to deal with a great amount of information about the topic (which might be an even greater challenge if the topic is abstract). Although students sometimes appreciate organizing their own class, they can encounter problems trying to decide what is relevant and what might be omitted. Giving clear and detailed guidelines can help students focus on the relevant information, as can pre-class feedback from the teacher on the relevance of the material chosen by the student.

\section{2) Everyone is alotted an equal amount of time to speak and everyone is listened to}

The question of engaging all the students equally is extremely important, given that there are always intoroverted students who never volunteer to talk but have plenty to say when asked to comment on topics discussed in class. As all teachers know, there are also many extroverted students who always feel invited to say something about any topic discussed in class, regardless of whether their contribution is relevant and of interest to all the other students in class. Giving everyone a small task and their own time to speak is a good way of dealing with both these types of students and ensuring equal treatment for all.

\section{3) Assigned topics might be a starting point for more extensive research}

Discussing sensitive topics such as war as part of their class, especially in a post-war period, is challenging for students. However, it can also help students develop their own ideas and attitudes to such topics. A year or two later into their studies, they might remember what they heard in the workshop class (or any other class) and decide to research their own or some other student's topic in more detail and with much more understanding. Given that these were all German majors and that many of the topics related to the history of Germany and Austria, as two German-speaking countries, there is a real possibility some of these topics might be used for the students' research in some other courses.

\section{4) Less abstract topics are more successful}

This success especially refers to better reasearch and more confident delivery. I believe this fact could be explained by the age and year of study of the students. As already mentioned, this group consisted of students in their second year of university study, which means they were nineteen or twenty, and I do not think most of them are prepared to tackle an abstract topic in the same way a more senior student would be able to. Naturally, there are individual differences among the students so it is a teacher's responsibility to decide what topics she/he would assign and what kind of delivery she/he would expect from her/his students.

There were, however, some negative sides to this class design. As wih any other takehome assignment, the teacher has no influence on how much material the student prepares and brings into class, which meant, in this particular case, that some students spoke for only 1 or 2 minutes (the instructions clearly stated "a maximum of 5 minutes"). Related to that is the fact that some students did their research very well, while others probably googled their topics not long before the class. Their involvement in the discussion varied to the extent that some of them wanted to comment on the topics mentioned but the others did not want to 
make any comments. Also, the time management could be done better as there was not enough time for comments after the individual presentations by the students. This, of course, depends on the number of students and good time-keeping.

\section{Students' conclusions}

As the class time ran out, the students were asked to think of concise conclusions to everything they heard that day. This was a brainstorming activity rather than a careful analysis of all the topics and comments, as it was almost the end of the class and there was not enough time and patience to discuss the topics any further. However, it is important to list the students' conclusions here because they are illustrative of what they thought about in the workshop. Here is a list of what the students thought of:

\section{Conclusions ${ }^{6}$ :}

War is bad.

War is a lesson.

There are no winners.

People are either good or bad.

We fight in a war for a higher authority.

If everyone was educated, there would be no war.

History repeats itself.

Every war is the same.

Some countries around the globe are at war.

\section{CONCLUSION}

The main idea behind this case-study was to observe the possibility of organizing the workshop class on war following the basic principles of the critical thinking approach and content-based language teaching. The students' take-home research assignment was combined with their short presentations in the class organized in a non-traditional manner, which were followed by the students' discussion based on the teacher's questions. The results were derived from the teacher's observations and students' responses during and after the workshop class. Although it is not easy to assess the results of adopting the critical thinking approach and it is difficult to obtain clear evidence to show the teaching was effective (Buskist and Irons, 2008), it is still possible to draw some conclusions from the teacher's own observations and students' responses in the workshop.

Based on the teacher's observations and students' responses, organizing an EFL class as a workshop to discuss a sensitive topic such as war is an excellent way to deal with such topics because students have an equal opportunity to present their pre-workshop research and express their thoughts on this difficult and uncomfortable topic. The teacher's role is the role of a moderator, which is a welcome modification of a traditional EFL class, where teachers are engaged in the class as much as their students (or even more than their students). The students' positive response to the altered seating arrangement (in a circle) indicates their desire to be treated as equal participants in the class, both among themselves and between them and the teacher. In addition to that, the students were all given the same amount of time to talk, were all expected to produce the same type of research and were treated with the same regard by the teacher and their classmates, which is in line with the critical thinking principle of communicating with students with respect rather than power or exploitation. (Smith, 1990,

\footnotetext{
${ }^{6}$ Entirely in the students' own words.
} 
p.107) When asked explicitly whether they had learnt something new in the workshop, the students all said they had, which indicates that the area from which the students obviously benefited was the knowledge of the workshop topic. (Liaw, 2007) Another observation refers to the enthusiastic atmosphere in the classroom. This is not something that can be explained in logical terms or quantified or proven to anyone but teachers might know what it means.

The negative aspects of the workshop class on a sensitive topic - the students' lack of focus, their involvement in the discussion and time management - could easily be resolved by providing students with clear instructions and guidelines in terms of what to emphasize and what they can mention in passing, how much context to explain, and how to structure their presentations within a time limit, to mention just a few.

All these observations are a good starting point to organize more workshops in the future that would replace the usual classes and might provide a better environment for students to critically think about topics from their syllabus and be more motivated. (Rezaei, Derakhshan and Bagherkazemi, 2011) Examples of what could be done are the following:

- a series of workshop classes designed around the syllabus topics based on the material for content-based learning

- a workshop class on different aspects of a sensitive or controversial topic, consisting of several groups of students simultaneously holding a small workshop on the different aspect of the topic, with a general discussion after their small workshops are finished

- take-home assignments given to small groups of students from the same class, who prepare a topic of their own choosing to discuss in a workshop class with all their classmates.

These are just some of the possibilities in terms of how a workshop class on a sensitive topic could be structured. Analyzing more of these classes with one or several groups of students over a semester or two semesters would certainly provide a better insight into the outcomes and advantages and disadvantages of this approach to teaching but there is no doubt that students benefit from this manner of learning in terms of gained knowledge on a topic, improved language skills, increased motivation, as well as a relaxing atmosphere in the classroom.

\section{REFERENCES}

Allison, J. (2014). Critical thinking: Critical choices. The Plymouth Student Scientist, 7(1), 12.

Atkinson, D. (1997). A critical approach to critical thinking in TESOL. TESOL Quarterly, 31(1), 71-94. Retrieved February 23, 2019 from https://focionline.files.wordpress.com/2014/05/dwight-atkinson.pdf

Bloom, B. S. (1956). Taxonomy of educational objectives: Classification of educational goals. Handbook 1: Cognitive domain. New York: Longman, Green \& Co.

Brookfield, S. (2012). Teaching for critical thinking: Tools and techniques to help students question their assumptions. San Francisco: Jossey-Bass.

Brown, H. D. (2004). Some practical thoughts about student-sensitive critical pedagogy. The Language Teacher, 28(7), 23-27.

Buskist, W. \& Irons G.J. (2008). Simple strategies for teaching your students to think critically. In D. S. Dunn, J. S. Halonen, and R. A. Smith(Ed), Teaching Critical 
Thinking in Psychology: A Handbook of Best Practices (pp.49 -57). UK: Blackwell Publishing Ltd.

Donaghy, K. \& Xerri, D. (eds.) (2017). The Image in English Language Teaching. Floriana, Malta: ELT Council, Ministry for Education and Employment

Dupuy, B. C. (2000). Content-based instruction: Can it help ease the transition from beginning to advanced foreign language classes? Foreign Language Annals, 33, 205223.

Elder, L. \& Paul, R. (2003). Critical thinking: Teaching students how to study and learn (Part IV). Journal of Developmental Education, 27(1), 36-37.

Ennis, R. H. (2002). A super streamlined conception of critical thinking. Retrieved 2020, December 6 from http://faculty.ed.uiuc.edu/rhennis.

Ennis, R. H. (2011). Critical thinking: Reflection and perspective, Part 1. Inquiry: Critical Thinking Across the Disciplines, 26(1), 4-18.

Facione, P. A. (2011). Critical thinking: What it is and why it counts. Millbrae, CA: California Academic Press. Retrieved February 20, 2019 from https://www.nyack.edu/files/CT_What_Why_2013.pdf

Gómez, L. F. \& Leal, M. (2015). Transactional Reading in EFL learning: A path to promoting critical thinking through urban legends. Colombian Applied Linguistics Journal, 17(2), 229-245. doi: http://dx.doi.org/10.14483/udistrital.jour.calj.2015.2.a04

Liaw, M. L. (2007). Content-based reading and writing for critical thinking skills in an EFL context. English Teaching and Learning, 31(2), 45-87.

Met, M. (1991). Learning language through content: Learning content through language.

Foreign Language Annals, 24, 281-295.

Moore, T. (2013). Critical thinking: seven definitions in search of a concept. Studies in Higher

Education, 38(4), 506-522.

Paul, R., \& Elder, L. (2005). Critical thinking competency standards. Foundation for Critical Thinking Press. Retrieved February 15, 2019 from: http://www.criticalthinking.org/TGS_files/SAM-CT_competencies_2005.pdf

Pineda Baez, C. (2004). Critical Thinking in the EFL Classroom: The Search for a Pedagogical

Alternative to Improve English Learning. Íkala, revista de lenguaje y cultura, 9(15), 45-80. Retrieved $\quad$ February $10, \quad 2019$ from https://www.redalyc.org/articulo.oa?id=255025901003 
Rezaei, S., Derakhshan, A. \& Bagherkazemi, M. (2011). Critical Thinking in Language Education. Journal of Language Teaching and Research, 2(4), 769-777. doi:10.4304/jltr.2.4.769-777

Shirkhani, S. \& Fahim, M. (2011). Enhancing critical thinking in foreign language learners. Procedia - Social and Behavioral Sciences 29, $111-115$. doi:10.1016/j.sbspro.2011.11.214

Shuy, R.W. (1981). A holistic view of language. Research in the Teaching of English, 15(2), 101-111.

Smith, F. (1990). To think. New York: Teachers College Press

Stoller, F. L. (1997). Project work: A means to promote language content. English Teaching Forum, 35(4), 2-9.

Yassin, A. A., Razak, N. A., \& Maasum, T. N. R. T. M. (2019). Integrated Model for Teaching Language Skills. International Journal of English Linguistics, 9(5).

Yuretich, F. R. (2004). Encouraging critical thinking: Measuring skills in large introductory science classes. Journal of College Science Teaching, 33(3), 40-46.

\section{$\underline{\text { AUTHORS' BIO }}$}

Maja Mandic,, MPhil. is an EFL instructor at the Faculty of Philology, University of Banja Luka (Bosnia and Herzegovina). She has taught syntax, translation, and Critical Discourse Analysis for years but her recent focus has been on using visual materials in teaching English as a Foreign Language, especially in the framework of developing critical thinking skills. 